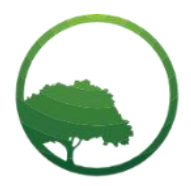

Research in Business \& Social Science

IJRBS VOL 10 NO 4 ISSN: 2147-4478

\title{
Rebuilding the concept of kaamilah sharia value added with the Qur'anic morals
}

\author{
(Di) Naimatul Hasanah ${ }^{(a) *}$ (iD) Iwan Triyuwono ${ }^{(b)}$ (i) Ali Djamhuri ${ }^{(c)}$ \\ (a) Accounting Department, Faculty of Economics and Business, University of Brawijaya, Malang, Indonesia \\ Crossref \\ (b) Professor in Accounting, Accounting Department, Faculty of Economics and Business, University of Brawijaya, Malang, Indonesia \\ ${ }^{(c)}$ Associate Professor in Accounting, Accounting Department, Faculty of Economics and Business, University of Brawijaya, Malang, Indonesia
}

\begin{tabular}{l} 
A R T I C L E I N F O \\
\hline Article history: \\
Received 12 May 2021 \\
Received in rev. form 25 May 2021 \\
Accepted 27 May 2021 \\
Keywords: \\
Value added, sharia value added, \\
kaamilah with the Qur'anic morals, \\
literature study \\
JEL Classification: \\
A13
\end{tabular}

\begin{abstract}
A B S T R A C T
This study aims to build the new concept of sharia value-added. Value added is the main concept of measuring income to find out the performance of an entity. Meanwhile, the sharia value added is the economic, mental and spiritual value-added. The kaamilah sharia value added with the Qur'anic morals is a construction of the value-added concept. This study used a qualitative method with the type of literature study research, namely research in which data collection was carried out by collecting data from various literature. The results of this study were the concept of kaamilah sharia value added with the Qur'anic morals, namely economic value added (in the form of money), mental and spiritual value added (in the form of altruistic sense, pleasure, brotherhood sense, justice, truth, honesty and trust, preserves nature, and the sense of God's presence) which is obtained, processed, and distributed in a halal manner and in which morals are attached as a vein in all aspects of life to carry out the mandate and responsibility of the intrinsic owner of the property, namely God.
\end{abstract}

(C) 2021 by the authors. Licensee SSBFNET, Istanbul, Turkey. This article is an open access article distributed under the terms and conditions of the Creative Commons Attribution (CC BY) license (http://creativecommons.org/licenses/by/4.0/).

\section{Introduction}

The development of sharia accounting studies is directly proportional to the rapid progress of the sharia-based business institution industry. The development of the world's sharia finance industry has experienced rapid growth in the last 10 years. Globally, the growth rate of sharia financial institutions reaches 17.3 percent per year (Meutia \& Febrianti, 2017). The review results were conducted by Mustofa (2013) stated that sharia accounting research in Indonesia has increased from year to year from 2001 to 2011. Based on the statement above, what is the difference between conventional accounting and sharia accounting?

The difference between sharia accounting and conventional accounting lies in the principles of sharia accounting that applies to the sharia business. These principles are, first, principle of accountability, second is the principle of justice, third is efficiency and effectiveness. Another thing that distinguishes between conventional accounting and sharia accounting is accountability. Financial accountability is an accountability regarding financial integrity, disclosure and compliance with financial management toward laws and regulations. Accountability based on sharia accounting is broadly the same as conventional accounting, which is related to reporting information to stakeholders. However, stakeholders in sharia accounting are divided into two, namely direct participant and indirect participant. Direct participants are parties who contribute to the company in the form of financial and non-financial (eg personnel and skill). Meanwhile, indirect participants are parties who do not contribute to the company at all, either in financial or non-financial forms, but with that status they have the right to a share of the welfare that has been successfully created and become the responsibility (accountability) of the company (Triyuwono, 2002b).

Accountability in Islam does not only cover stakeholders in general, stakeholders (investors, government, creditors, society). However, the obligations of the Muslim community also include responsibility towards other communities whose economies are

* Corresponding author. ORCID ID: 0000-0002-1062-703X

(C) 2021 by the authors. Hosting by SSBFNET. Peer review under responsibility of Center for Strategic Studies in Business and Finance.

https://doi.org/10.20525/ijrbs.v10i4.1178 
inadequate. Thus we as Muslims have fulfilled our responsibility to God by carrying out mu'amalah according to Islamic law. That is why God metaphorically describes Himself as sick, hungry and thirsty. It means, when we want to meet our God, then immediately meet our relatives who are suffering from misfortune, lying sick, and hungry. There are not a few hadiths of the Prophet which stated the importance of individual piety side by side with social piety. One of them is that we are not called believers, said the Prophet, when we sleep soundly and our stomachs are full, while at the same time, our relatives, our neighbors feel their stomachs rumbling from hunger.

The concept of value added has been widely applied in companies, one of which is the mu'amalat bank, mandiri syariah bank and many other companies that also apply value added report. However, there is no clear explanation about the nominal symbols that is stated in the value added report, especially regarding their compatibility with Islamic principles in distribution. This is still a big question mark. Economic inequality that occurs in the country is very alarming and is a common phenomenon. The factor that causes this is due to injustice and imbalance in the distribution of income and wealth (Kalsum, 2018). Because the imbalance of income distribution is a source of individual and social conflict (Nasution: 2007, 120). If the distribution of wealth is not right, most of the wealth will go into the pockets of the capitalists and as a result many people who suffer from poverty and the excess wealth of the country, they do not enjoy.

The goals that Islam wants to achieve cover all sectors including the economic sector in accordance with the goals and values of Islam. With the goals and values of Islam can determine the nature of the Islamic economic. Therefore, a proper understanding of the Islamic economic system is crucial. The goals and values of Islam are: first, economic welfare within the framework of Islamic norms. Second, universal brotherhood and justice. Third, fair income distribution. Fourth, individual freedom in the context of social welfare (Chapra:1992,1). Apart from Chapra, Baydoun and Willet (1994,2000), Wulger (2000), actually have contributed to value added, but only limited to the form of presentation in the value added report.

Mulawarman (2006) contributed to the value added report that has formed the sharia value added report. It is different from Triyuwono (2007) which in this case contributed to the concept of sharia value added which includes economic, mental and spiritual value added that is obtained, processed and distributed in a halal manner. However, Triyuwono again said that the value added that he formulated was more complex than the value added of a modern economy, so further research is still needed to more concretize the sharia value added. This encourages me as a researcher to continue research on the concept of sharia value added in order to learn more deeply about the concept of sharia value added which is more concrete, deeper and broader. So, from the explanation given above, it is clear that in the future a broader study is still needed on how the concept of sharia value added is, so the problem formulation in this research is "how is the construction of the concept of sharia value added?"

\section{Literature Review}

\section{Theoretical and Conceptual Background}

\section{Value Added}

Value added is a measure of the performance of an economic entity that has a long history of application in economics (Haller and Stolow 1995). Value added is the main concept of measuring income. The concept of value added has traditionally been rooted in macroeconomics, especially in relation to the calculation of national income. VA is measured by the productive performance of the national economy which is usually called a national or domestic product. National income represents the value added of the national economy in a specific period. Its universal use of the concept of value added has also been widely discussed and practiced as an economic utility and performance indicator in different areas of economics and business.

\section{Accountability in Sharia Accounting}

Accountability according to Triyuwono (2002 b) is the spirit (utility) of sharia accounting. The concept of accountability is closely related to the Islamic understanding tradition of God, human and the universe. In the Islamic tradition, humans are khalifatullah fil ardh (representatives of Allah on earth) with a special mission to spread mercy to all of nature as a mandate to manage the earth based on God's will. This means, continued Triyuwono, humans are obliged to manage the earth based on sharia ethics, the consequences must be accountable to God. Accountability like this is called the main premise of vertical accountability. However, it must be admitted that the human task is a grounded task, which in a micro context means that a business entity has entered into a social contract with society and nature. As a consequence of the contract according to Triyuwono (2002b) an agent must be responsible to the society (stakeholders) and nature (universe). This is known as horizontal accountability. The accountability of Triyuwono is an accountability that is centered on the human task in God's universe as khalifatullah fil ardh.

\section{Information in Sharia Accounting}

According to Triyuwono (2002b) accountability as a representation of spirit is one side of the sharia accounting coin. The other side is the provision of information as a material embodiment. Sharia value accountability is the spirit that underlies forms of accounting and accounting information, both quantitative and qualitative, economic, social, spiritual and business politics, which are used for decision making by interested parties. Providing information is not limited to provide quantitative information, as in modern accounting, but also qualitative information, both economic and social, spiritual and mental in nature. It should be noted that the goal 
of sharia accounting information even though it is a material embodiment actually consists of both material and non-material information. The consequence of material information is in the form of quantitative information, while non-material information is in the form of qualitative information.

\section{Islamic Economic as an Analysis Tool}

The foundation of the Islamic economic as stated by the Al-Lajnah Ad-Daa-imah Lil Buhuuts Al-Ilmiyah Wal Ifta Saudi Arabia scholar is muamalah which is based on sharia, namely by developing assets through methods that are permitted by Allah Ta'ala, in accordance with the rules and regulations of muamalah syar'iyyah, which are based on the basic law, are permissible and halal in various muamalah, and stay away from everything that is forbidden by Allah from them. Business is not only influenced by internal and external conditions, but also influenced by individual mood. Business decisions are not only based on the calculation of financial predictions, but the peak is on intuition, mental and inner mood (Mulawarman 2011). In order to critically look at the concept of value added, this study used the concept of Islamic economics as an analytical tool. The reason researcher used the concept of Islamic economics as an analytical tool is because accounting has been known as an economic instrument (Muhamad, 2005). Accounting has a role that cannot be separated from its function as a pillar for the economic system (Harahap, 2001).

Sharia accounting is one of the elements to realize an Islamic economic system that must support and facilitate the operation of the Islamic economic system. Islamic economy itself has a role as a pillar for the creation of an Islamic society that is blessed by Allah SWT. With this background, the researcher took the concept of Islamic economics as a critical analysis tool for the concept of sharia accounting, especially the concept of sharia value added. Furthermore, the critical analysis tool in this study was limited to only three indicators taken from the concept of Islamic economics, namely morals in muamalah, the concept of income distribution, and the principle of convenience. The reason researcher took these three indicators was that these three indicators showed characteristics that distinguish between sharia accounting and conventional accounting. The moral or culture indicator will show the value held in sharia accounting. The concept of income distribution will show the orientation of sharia accounting. The principle of convenience shows that the role of sharia accounting in muamalah has the characteristics of providing information in the best and easy ways that can be understood by various parties.

\section{Sharia Value Added}

Triyuwono (2007) argued that the sharia value added is the value added of the mental and spiritual economy that is obtained, processed and distributed in a halal manner. Meanwhile, according to Mulawarman (2006) the syaria value added as an income concept in syaria accounting is a form of value added that has been declared, which is halal, thoyib and free of usury. The sharia value added like this comes from the treatment of ta'wil (metaphor) on the zakat concept. From the ta'wil of zakat concept, value added reconstruction can be carried out. Sharia value added is a form of value added (zakka) that occurs materially (zaka) and has been purified (tazkiyah) spiritually (non-material).

Therefore zakat is a symbol of purification from added which must be valued of balance and justice. The implication of balance and justice in the sharia value added is the formation of three main benefits. First, the process of forming the sharia value added must be carried out consistently by adhering to the principles of truth and not violating God's provisions (halal and thoyyib). Second, the growth of assets and a healthy business mechanism must be carried out in the framework of eliminate excessive nature in obtaining property. The form is to carry out usury-free business activities in all its forms (financial reduction in the form of ba'I and social and environmental reduction in the form of shadaqah. Third, implication in the form of distribution must be carried out optimally for the good of others, equitable and not negating each other. Laying down the principle of balance and justice based on divine morals (Divine Justice)

\section{Moral}

The word "Akhlaq" comes from Arabic, which means character, temperament, behavior, and/or character. Then it was adopted into the Indonesian language, namely "akhlak". But in Al-Qur'an, the word that can be found is the singular form of the word "akhlaq", namely khuluq in the al-Qur'an, surah al-Qalam (68) verse 4: "And Surely, you (Muhammad) is truly a great character." In Islam, the closest term to ethics is is "khuluq", as in the surah above. However, if examined more deeply, it turns out that the al-Qur'an also used a number of other terms to describe the concept of morals, namely khayr (goodness), birr (truth), Qist (equality), 'adl (equality and justice), haqq (truth and kindness), ma'ruf (knowing and agreeing), and taqwa (piety).

The word moral which has become the Indonesian language is defined as the knowledge that determines the boundaries between good and bad, between the praiseworthy and the despicable, about the words and actions of human beings both physically and mentally (Ya'qub, 3:1991). Behind physical behavior, there is still a heart (qalb) that can determine a person's morals. This is the advantage of the teachings of morality in Islam which teaches that what is said by human beings who have morals is those who behave in accordance with the provisions of the Sharia, both physically and mentally (tazkiyah al-dahr wal al-qalb aw batn). Therefore in the process of obtaining value added in accounting, especially the sharia value added, of course, is never separated from morals.

From the perspective of Islamic ethics (morals), in principle, humans are required to do good to themselves, in addition to their fellow humans, their natural environment and to God as His Creator. If humans have done good in the last third (external), then in essence humans have done good to themselves (internally). Therefore, to be able to do good to all of them, apart from being given freedom 
(freewill), human should pay attention to the oneness of God (Tawhid), the principle of balance (tawazun=balance), justice (qist). Besides the responsibility that will be given before God.

\section{Qur'anic Morals as Accountants' Guidelines}

In sharia accounting, al-Qur'an is a guideline that is used as a reference for accounting actors in every business activity. This is because sharia accounting is accounting based on sharia principles, where the basic guidelines are contained in the al-Qur'an. Sharia accounting is inseparable from the Islamic syariah system brought by the Prophet Muhammad SAW, unlike the conventional accounting system which separates the role of religion from the economy and its business activities. There are several examples of qur'anic morals that are used as guidelines for economic actors, including the demands for justice, honesty, balance and many other examples.

Islam recognizes the position of humans as social beings who are muamalah and cannot be separated from transactions and business activities. However, Islam as a religion still prioritizes the boundaries of business activities in the rules that are in accordance with sharia (Zuhayli, 2013). So if the previous sub-chapter explained about accounting (especially value added) which is based on Qur'anic moral, then in this sub-chapter what is expected is when the concept of sharia value added with Qur'anic morals has been born, then in the future the accounting actor or accountant are also be able to carry out accounting activities with Qur'anic morals.

\section{Research Methodology}

This research was an accounting research with qualitative method. This type of research was library research, namely research in which data collection was carried out by collecting data from various literatures. Meanwhile, the literature studied was not only limited to books, but also in the form of documentation, magazines, journals, websites, Al-Qur'an and Hadiths. Library research is a theoretical study, references and other scientific literature related to culture, values and norms that develop in the social situation under study (Sugiyono: 2012). This literature research aims to find the concept of sharia value added to solve the problems faced. This research collected data from the literature treasure and makes text as the main object of analysis. The data obtained, compiled, arranged, and grouped into themes and sub-themes were then analyzed, interpreted proportionally and critically reviewed with textual analysis and contextually applied according to research needs.

The research methodology was chosen by the researcher namely the construction method, which is the creation, design, preparation of a concept. This research constructed the concept of sharia value added which consists of economic, mental and spiritual value added into sharia value added which consists of kaamilah economic, mental and spiritual value added with the Qur'anic morals. In this study, researcher used Islamic economic analysis tools. Islamic economics has several bases. First, mu'amalah syar'iyyah (moral) culture, second the concept of income distribution, third principle of convenience. Researcher tried to rebuild the concept of sharia value added which may be better and more perfect than the previous existing concepts in accordance with sharia principles.

\section{Sharia Value Added Forms in the Frame of Reality}

The sharia value added is economy, mental and spiritual value added that is obtained in a halal manner. In addition, the sharia value added is also a representation of the concept of zakat, which is a form of value added in the form of material and has gone through a spiritual purification process. Thus, zakat is a symbol of purification and added which must have the value of justice and balance. Meanwhile, the sharia value added is a value added that has been declared halal, toyyib, and free of usur

Table 1: The forms of kaamilah sharia value added with the Qur'anic moralsy.

\begin{tabular}{lll}
\hline No & Value Added & Value Added Forms \\
\hline $\mathbf{1}$ & Economy & Money \\
\hline $\mathbf{2}$ & Mental, Spiritual & $\begin{array}{l}\text { Sense of altruistic, pleasure, and brotherhood, justice, truth, honesty and trust, } \\
\text { sincerity, preserves nature and a sense of God's presence. }\end{array}$
\end{tabular}

The kaamilah sharia value added with Qur'anic morals is a construction of sharia value added with several forms of value added, namely, economic value added in the form of money distributed in the form (zakat, infaq and sadaqah), mental and spiritual value added in the form of (sense of altruistic, pleasure, brotherhood, justice, truth, honesty and trust, sincerity, preserves nature, and a sense of God's presence). The form of mental and spiritual value added in this case is united because the contents of mental and spiritual value added are both morals, and morals are worship that is carried out continuously in daily life. This sharia value added has a wider scope than the existing sharia value added, because the sharia value added was established by this researcher teaches that humans should not only have humanity but must also be victorious because of the animals, plants and the surrounding environment as well as including God's creatures whose preservation must also be preserved, so that no exploitation occurs either in humans, 
animals, plants or the surrounding environment. Therefore, in this concept, humans are not only responsible to humans as stakeholders, but humans must also be accountable for all their actions on earth to the owner of intrinsic wealth, namely God.

\section{Economic Value Added}

Economic value added in the form of money is distributed in the form (zaka infaq and sadaqah). The distribution program in Islam consists of three parts. First, providing assistance in the form of finding/providing jobs for the unemployed and remuneration/salary/wages for those who are already working. Second, the payment of zakat so that it can be redistributed to people who are physically, mentally disabled or people who cannot achieve a better standard of living by their own efforts, so that wealth does not only circulate among certain groups Q.S (59: 7). In Islam there is the principle of rahmatan lil 'alamin, which means that human existence should be beneficial to other creatures of Allah. In the sharia framework, the benefits of the existence of a shariabased business institution should be felt by all parties, whether involved or not directly involved in sharia business activities. This form of grace or partisanship can be in the form of giving zakat, infaq and sadaqah as well as providing financing to small entrepreneurs.

\section{Mental and Spiritual Value Added}

The mental and spiritual value added is first described in the form of an Altruistic Sense (being concerned with others). The role of integration in the concept of tawhid will create a feeling in man that he will always feel that all his life activities are recorded, including in economic activities (including accounting). Doesn't God have the character of raqib (omnipotent) on all the movements of the life activities of His creatures. Thus, constant attention to fulfilling ethical guidance will increase individual awareness which in turn will increase the strength and sincerity of his altruistic instincts, both in fellow humans and in the natural environment. In the concept of ownership in Islam there is the principle of ijtima'iyah which in principle teaches Muslims to have an attitude of sympathy, empathy, and togetherness, in their capacity as social beings who need each other. If this principle is applied in the business world, business people will have the sensitivity to help the weak. Of course, how honorable are the wealth holders (aghniya) who are able to build their altruistic morals for the common good.

The second, sense of brotherhood (ukhuwah islamiyah), the consequence of the concept of brotherhood is cooperation, especially among Muslims, apart from being united to one another as human beings, but also united by the same ideological ties that have been characterized in the al-Qur'an as relatives in faith as has been mentioned in the al-Qur'an surah at-Taubah verse 11. Love, affection. Mutual assistance which is attached to human beings will develop a feeling like the body, where if one part feels pain, then the other part will also feel uncomfortable.

The third is pleasure, wealth needs to be directed to increase the benefits in his life, on the contrary to narrow the harm, both to the owner and to others. Without giving much benefit, the wealth will undoubtedly have no meaning in life, because after all God bestows that wealth solely for the benefit of man himself. Both wealth is for happiness in this world and salvation in the hereafter. Conversely, if wealth is really used for various forms of goodness, it will undoubtedly be blessed. Blessings that bring pleasure (sa'adah), enjoyment, and additional sustenance (ziyadah) in it which in turn will bring peace to the owner.

The fourth Sense of Sincerity, talking about sincerity in accounting, sometimes someone who is sincere prefers if what he contributes to or what he gives to individuals, companies or institutions is not given proof of transactions or even if they are willing to be recorded by the company/institution concerned only as a report for the responsibility of the parties concerned, however, the giver asks to keep his name secret, not without reason, but the giver does not want the sincerity in his heart change to a sense of riya' which actually causes heart disease for him. He feels that Allah knows enough about the good that he does, that is sincerity which is reflected in the reality of life.

The fifth, Islamic economics has two forms of justice. First, fair wages for employees are applied by setting maximum working hours, creating decent working conditions and enforcing preventive measures against industrial hazards, will be in accordance with the spirit of Islamic teachings. The second form of justice is justice for superiors/entrepreneurs. In addition to Islamic employees, it also demands justice to protect employers (employers/superiors) by placing certain moral obligations on employees as well as by doing work carefully, diligently and with the maximum possible skill, must honest and trustworthy. Thus, if Islam has placed a number of obligations on superiors, employees are also expected to be able to do their work carefully and diligently, as well as be honest and trustworthy. The goal is justice for employers and employees in all economic relationships. Only with harmonious arrangements and shared responsibilities that emphasize cooperation and fulfillment of obligations with care, in an environment of brotherhood, justice and moral values, which can minimize conflicts within the company and build industrial peace.

The sixth is truth, the source of the value of truth is what comes from God and is directly practiced by His Messenger among mankind. Regarding this statement, presumably no one can deny it as long as one still wants to think objectively scientifically in seeing the truth. Or in other words, the values contained in Islamic ethics are the teachings of the heavens which need not be doubted its piety. In it is implied absolute truth (itlaq) which often still requires in-depth interpretation which needs to be done by a competent expert so that its authenticity is maintained.

The seventh is honesty and trust, the issue of honesty is not only the key to the success of a businessman according to Islam. But modern business ethics also places great emphasis on honesty. In a relationship, trust is a fundamental element. Trust results from 
sincerity which is one of the character qualities that are so difficult to achieve in business, family or other places where one's selfinterest competes with the interests of others. Based on the statement above however, trust is very basic in muamalah activities. In business to build a framework of trust, a person must be able to act honestly, fairly, both to himself and others.

The eighth, preserving nature, humans have the authority to take advantage of the produce of the land and everything that lives on it such as plants and animals that have been provided for free by Allah SWT, so humans have the right to use it. But what needs to be remembered is, humans must also be responsible and still take care of it. This utilization does not mean that humans can use it at will, but it needs responsible and sustainable use.

Forms of value added such as (sense of altruistic, pleasure, and brotherhood, justice, truth, honesty and trust, sincerity). Some of them are also included in Asma'ul Husna such as (al-Adl and al-Haqq), but the most important thing is that the sharia value added is also a form of worship to Allah. The word ibadah comes from Arabic, it is mashdar and the word 'abada, ya'budu, ibaadatan", which means obedience, submission, enslavement, prayer, servitude, worship etc. Humans were created by God only to serve Him. The form of human devotion to God can be in the form of ritual activities that are directly related to God and activities that bring benefit to others. This means that with a sense of altruism, pleasure, brotherhood, honesty, justice and a sense of sincerity are forms of devotion human beings to God as stated in their daily activities or muamalah. All of them are forms of worship (obeying and submitting to all the commands of Allah) so that the mental and spiritual value added here I combined into one because all of them are morals that have the value of worship.

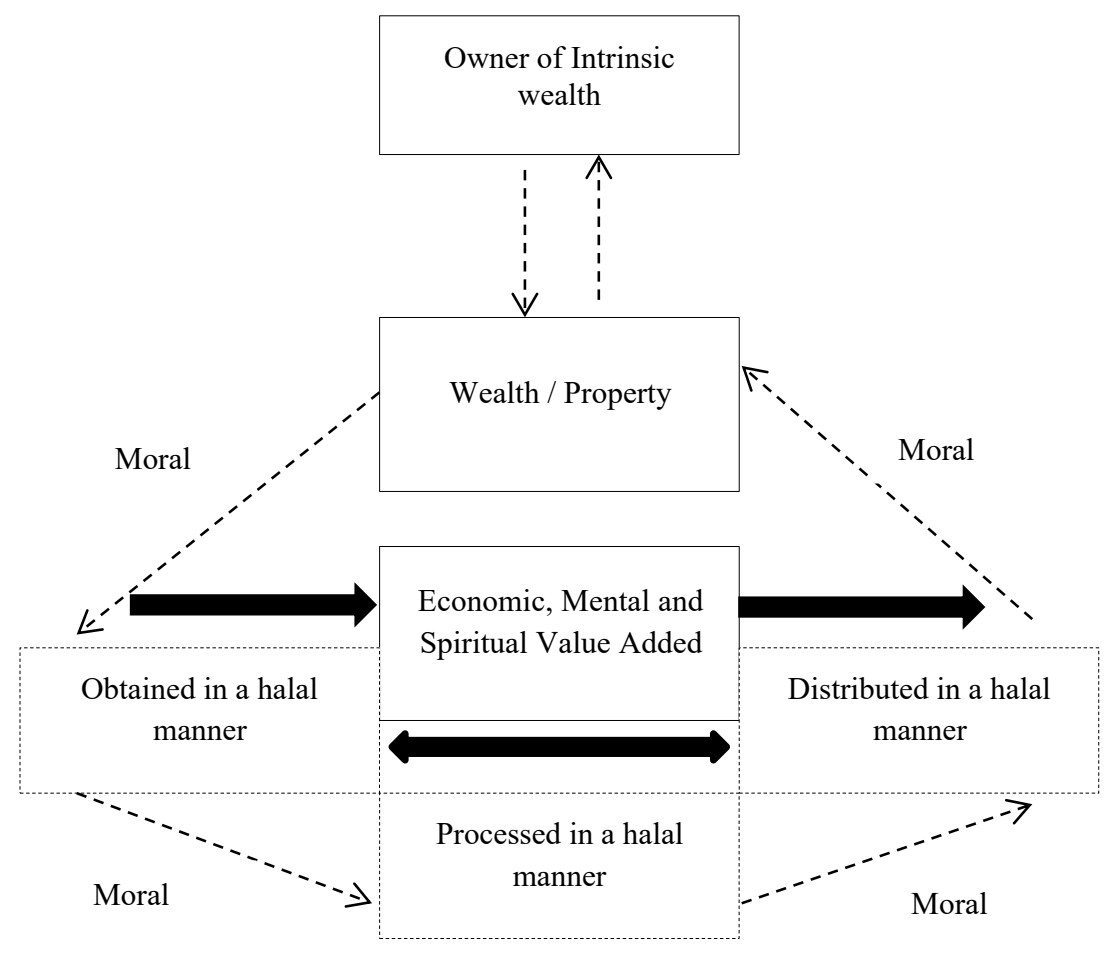

Figure 1: Kaamilah Sharia Value Added with the Qur'anic Morals

In Islam, it is not only worship that has the principles or basis of the al-Qur'an as its foundation. However, regarding economic, social, cultural, political and other muamalah lines also have the principle of the al-Qur'an as a basis for including accounting (in this case the sharia value added). In contrast to value added in the sense of (conventional accounting) that separates accounting and religion, Islam makes accounting (in this case the sharia value added) stand on a clear foundation, namely the al-Qur'an, so it is said that in accounting it cannot be separated by religion. According to Qardhawi (2004), Aqidah is the principle of the Islamic system. Where this principle consists of several elements including; First, faith in Allah swt. Second, the provision of Allah SWT that makes humans as a caliphate (khalifatullah fi lard). Third, Allah SWT does not differentiate between his servants except with their taqwa. Fourth, Allah SWT always guides people by giving instructions in the form of holy books and apostles. Fifth, Allah SWT perfected His direction and guidance by sending the Prophet Muhammad as the last prophet, the prophet who completes sharia and morals, and the prophet who perfected the benefit of all people. Sixth, Allah SWT determines human life not only to eat like animals, but more noble than that, namely worship (abd 'Allah) seeking solely Divine pleasure. 
The unity between accounting and morals will be increasingly clear at every step of the mu'amalah, whether related to production, distribution, circulation and consumption. Muslim is not free to do whatever he wants, or whatever benefits him. This is because a Muslim is bound by the ethical and moral rules contained in the al-Qur'an. If we pay attention to the reality on the ground, we will find the impact of the union between economy and morals, including in terms of accounting, especially the sharia value added, this is clearly and deeply in the history of the Muslims. This appears especially at the first time Islam has an influence on the lives of Muslims and becomes an influence especially on their activities and behavior (Qardhawi, 2004). This is in line with the hadith of the prophet narrated by Abu Hurairah ra, the Messenger of Allah said: "Surely I was sent to perfect morals". (HR. Baihaqi).

Based on the explanation above, the qur'anic morality serves as the basis of accounting itself, which in this case is specifically focused on the concept of sharia value added. Because morals cover all lines of life, including accounting. Then why is the sharia value added also based on qur'anic morals? the answer is, because the value added itself is an economic value added (in the form of money), mental and spiritual value added (in the form of a sense of altruism, pleasure, and brotherhood, justice, truth, honesty and trust, sincerity, preserving nature and a sense of God's presence) which is the essence of the Qur'anic moral itself. Thus, morals become the flesh and veins of Islamic life that cannot be separated in any field, so that accounting (in this case sharia value added) is born based on Qur'anic morals to perfect (kaamilah) the concept of value added that has been there before.

\section{Conclusion}

Sharia value added is the value added of the economy in the form of money distributed in the form (zakat, infaq, and sadaqah), mental and spiritual in the form (sense of altruistic, pleasure, and brotherhood, justice, truth, honesty and trust, sincerity, preserving nature and a sense of God's presence.) which is obtained, processed and distributed in a halal manner which includes morals as the vein in all aspects of life (including accounting) as a form of worship and to carry out the mandate and responsibilities of the intrinsic owner of the property, namely God, Because in truth property for humans is only the provision of temporary property rights from God so that it is managed by humans which in the end will still return to the owner of the intrinsic property rights.

Based on the statement above, I added the moral component and the concept of ownership in the concept of sharia value added. However, further research is still needed regarding other components or aspects that I have not included in the concept that I have compiled or how to disclose it? how is it presented? how is the impact? or maybe there are still many other questions that can be arranged by further researchers to further enrich the study of sharia accounting, especially the sharia value added.

\section{References}

Baydoun, N., \& R. Willett. (1994). Islamic Accounting Theory. Paper Presented at The AAANZ Annual Conference. Baydoun, N., \& R. Willett. (2000). Islamic Corporate Report. ABACUS. 36 (1): 71-90.

Chapra, Muhammad Umar. An Introduction to Islamic Finance. Edited by: Syeikh Ghazali Sheikh abod, Syed Omar Syed Agil, Aidit Hj. Ghazali. Quil Publishers. Malaysia. 1992.

Harahap, Sofyan Syafri. (2001). Menuju Perumusan Teori Akuntansi Syari'ah. Pustaka Quantum. Jakarta.

Kalsum, Umi. (2018). Distribusi Pendapatan dan Kekayaan dalam Ekonomi Islam. Jurnal Studi Ekonomi dan Bisnis Islam, 3, (1).

Meutia, Intan. (2010). Shariah enterprise theory sebagai teori dasar pengungkapan tanggung jawab sosial Bank Islam. JurnalAkuntansi. Universitas Brawijaya.

Muhammad. (2004). Teori Penilaian dalam Akuntansi Syari'ah. MSI-UII.Net.

Mulawarman, Aji Dedi.,Triyuwono, iwan.,\&Ludigdo, Unti. (2006). Rekonstruksi Teknologi Integralistik Akuntansi Syariah: Shariate Value Added Statement.

Mulawarman, Aji Dedi. (2006). Menyibak Akuntansi Syari'ah. Yogyakarta: Kreasi Wacana.

Mulawarman, A. D. (2011). Elimination of Riba Through (Purification) (Tazkiyah) of the cash flow: A Study From The Indonesian Islamic Business Habitus. In Proceeding of the 9th Annual International Conference on Accounting, Athens 4-7 July

Mustofa. (2013). Trend Penelitian Akuntansi Syariah di Indonesia pada Awal Abad 21. Skripsi tidak diterbitkan. Surakarta: Universitas Sebelas Maret.

Nasution, Mustafa Edwin., Setyanto,B., Huda, N., Mufraeni M.A.,\& Utama, B.S. (2006). Pengenalan Eksklusif Ekonomi Islam. Jakarta: Kencana.

Sugiyono. (2012). Metode Penelitian Kuantitatif Kualitatif dan R\&B. Bandung: Alfabeta.

Sukoharsono, E. G.(2009). Laba Akuntansi dalam Multiparadigma. Malang: Tunas Unggul.

Qardawi, Yusuf. (2004). Peran Nilai dan Moral dalam Perekonomian Islam .Jakarta: Rabbani Press.

Triyuwono, Iwan. (2007). Mengangkat "Sing Liyan ”Untuk Formulasi Nilai Tambah Syari'ah. Makalah disampaikan dalam SNA 10 UNHAS 26 - 28 Juli 2007 Makasar.

Triyuwono, Iwan. (2002a). Kritik atas Konsep Teori yang Digunakan dalam Standar Akuntansi Perbankan Syari'ah. Seminar dan Munas FSSEI. FE-Universitas Brawijaya. Malang.

Wurgler, Jeffrey. (2000). Financial Markets and the Allocation of Capital. Journal of Financial Economics. 58: 187-214.

Ya’kub, Hamzah. (1991) Etika Islam, Bandung: CV. Diponegoro. 
Al-Zuhaili, W. 2013. Maqhosid al-Syariah al-Islamiyah fi al-Mal wa al-Iqtishad alIslami, makalah disampaikan dalam seminar $\neg$ e Second Islamic Economics and Finance Research Forum oleh Ikatan Ahli Ekonomi Islam di UIN Syarif Hidayatullah Jakarta 13-14 November 2013.

Publisher's Note: SSBFNET stays neutral with regard to jurisdictional claims in published maps and institutional affiliations.

\section{(a) (1)}

(C) 2021 by the authors. Licensee SSBFNET, Istanbul, Turkey. This article is an open access article distributed under the terms and conditions of the Creative Commons Attribution (CC BY) license (http://creativecommons.org/licenses/by/4.0/).

International Journal of Research in Business and Social Science (2147-4478) by SSBFNET is licensed under a Creative Commons Attribution 4.0 International License. 